\title{
Phytoextraction potential of sunflower and white mustard plants in zinc-contaminated soil
}

\author{
Marta Zalewska $^{1 *}$, and Anna Nogalska ${ }^{1}$
}

Phytoextraction relies on plants with a high capacity to absorb heavy metals and remove them from the soil. The objective of this study was to analyze the potential of sunflower (Helianthus annuus L.) and white mustard (Sinapis alba L.) for phytoextraction of $\mathrm{Zn}$-contaminated soil. Research was based on a strict pot experiment conducted in a greenhouse. Seven treatments were established with increasing Zn concentrations: 0, 25, 50, 100, 200, 400, and $600 \mathrm{mg} \mathrm{Zn} \mathrm{kg}^{-1}$ air-dry soil. The first tested plant was fodder sunflower. In the following year, white mustard was sown in the same pots. Plants were harvested at the end of the flowering stage. The toxic effect of $\mathrm{Zn}$ on sunflower yields occurred at the contamination level of $200 \mathrm{mg} \mathrm{Zn} \mathrm{kg}^{-1}$ soil. In the second year of the experiment, a significant decrease in mustard biomass took place in response to $400 \mathrm{mg} \mathrm{Zn} \mathrm{kg}^{-1}$ soil. The contamination level of $600 \mathrm{mg} \mathrm{Zn} \mathrm{kg}^{-1}$ soil resulted in complete plant death. Plant growth was not inhibited even at high tissue $\mathrm{Zn}$ concentrations of $515 \mathrm{mg} \mathrm{Zn} \mathrm{kg}{ }^{-1}$ sunflower DM and $422 \mathrm{mg} \mathrm{Zn} \mathrm{kg}^{-1}$ mustard DM. The 2-yr cropping system did not contribute to a significant decrease in soil $\mathrm{Zn}$ content. Despite high concentrations of $\mathrm{Zn}$ in sunflower and mustard plants, total $\mathrm{Zn}$ uptake accounted for only $1 \%$ to $8 \%$ of the $\mathrm{Zn}$ rate introduced into the soil. However, in the long run, the growing of crops could reduce $\mathrm{Zn}$ contamination levels in the soil. The relatively high tolerance of sunflower and white mustard for $\mathrm{Zn}$ contamination and rapid growth of these species are possible alternatives for phytoextraction and phytostabilization of Zn-contaminated soil.

Key words: Helianthus annuus, Sinapis alba, zinc accumulation, zinc toxicity, soil contamination.

\section{INTRODUCTION}

In Poland, the percentage of $\mathrm{Zn}$-contaminated soils is relatively high compared with soils polluted with other heavy metals and is estimated at $11 \%$ (Terelak et al., 1997; 2002). Zinc is characterized by high mobility in soil and is accumulated in large quantities by plants, and thus poses a serious environmental threat (Vaněk et al., 2005; Zalewska, 2012).

Chaney (1983) was the original author of phytoremediation techniques for soils contaminated by heavy metals. The initial concept was based on hyperaccumulator species that are capable of absorbing large quantities of heavy metals and are resistant to high metal concentrations in the soil. The scope of research in phytoremediation has been considerably extended, and now also covers mechanisms responsible for uptake and translocation of trace elements (Krämer et al., 1996; Lasat et al., 1998; Salt et al., 1999). Attempts are being made to explain increased tolerance to high concentrations of

\footnotetext{
${ }^{1}$ University of Warmia and Mazury in Olsztyn, Chair of Agricultural Chemistry and Environmental Protection, ul. Oczapowskiego 8, 10718 Olsztyn, Poland.

*Corresponding author (marta.zalewska@uwm.edu.pl).

Received: 5 February 2014.

Accepted: 11 August 2014.

doi:10.4067/S0718-58392014000400016
}

heavy metals of various plant species. Plants are also genetically modified to enhance their phytoremediation potential (Kärenlampi et al., 2000; Clemens et al., 2002; Pavlíková et al., 2004; Krämer, 2005).

Another line of research concerns using selected crop plants in the phytoextraction process. Heavy metal concentrations in their tissues are not as high as in hyperaccumulators, but crop plants are capable of producing very large quantities of biomass even in highly polluted soils, which increases the effectiveness of purification. The efficiency of phytoextraction can be improved by adding various chemical compounds to the contaminated substrate, which increase solubility and uptake of metals by plants (Blaylock et al., 1997; Huang et al., 1997).

Phytoextraction is a relatively inexpensive and easy technique compared with chemical methods to remove heavy metals from the soil; however, according to numerous reports, it is characterized by low efficiency (Ernst, 2000; Zalewska, 2012). Management of biomass containing large amounts of toxic metals also poses a problem (Ernst, 2000; Sas-Nowosielska et al., 2004). After phytoextraction, heavy metals can partially remain in the soil in plant roots that contain much higher levels of heavy metals than harvested above-ground plant parts.

The aim of this study was to analyze the potential of two crop plants, silage sunflower and white mustard, 
for phytoextraction of soil with various levels of $\mathrm{Zn}$ contamination.

\section{MATERIALS AND METHODS}

A pot experiment was conducted in the greenhouse of the University of Warmia and Mazury in Olsztyn. Seven treatments were established with increasing $\mathrm{Zn}$ concentrations: control (without Zn), 25, 50, 100, 200, 400, and $600 \mathrm{mg} \mathrm{Zn} \mathrm{kg} \mathrm{air-dry} \mathrm{soil.} \mathrm{Each} \mathrm{treatment} \mathrm{was}$ replicated four times.

Pots were filled with $8.0 \mathrm{~kg}$ of air-dry soil with the granulometric composition of loamy sand, which contained $81.3 \%$ sand (fraction $2.0-0.05 \mathrm{~mm}$ in diameter), $16.9 \%$ silt (fraction $0.05-0.002 \mathrm{~mm}$ in diameter), and $1.7 \%$ clay (fraction $0.002 \mathrm{~mm}$ in diameter) according to the USDA textural soil classification. Concentration of available forms of $\mathrm{Zn}$ (extraction in $1 \mathrm{M} \mathrm{HCl}$ ) was 13.56 $\mathrm{mg} \mathrm{Zn} \mathrm{kg}{ }^{-1}$ soil, organic $\mathrm{C}$ content $8.49 \mathrm{~g} \mathrm{~kg}^{-1}$ soil, and $\mathrm{pH}$ 5.78 in $1 \mathrm{M} \mathrm{KCl}$.

The first tested plant was fodder sunflower (Helianthus annuus L., 'LG 53.85'). White mustard (Sinapis alba L., 'Barka') was sown in the same pots the following year. Plants were harvested at the end of the flowering stage. After emergence, six sunflower plants and nine white mustard plants were left in each pot. Soil moisture content was maintained at $60 \%$ of maximum water-holding capacity. Before sowing, soil was treated with increasing doses of $\mathrm{Zn}$ in the form of $\mathrm{ZnSO}_{4} \cdot 7 \mathrm{H}_{2} \mathrm{O}$. Nitrogen, $\mathrm{P}$, $\mathrm{K}$, and $\mathrm{Mg}$ fertilizers were supplied at a constant rate in all treatments. The following were applied to each pot before sowing sunflower: $0.8 \mathrm{~g} \mathrm{~N}$ (as $\mathrm{NH}_{4} \mathrm{NO}_{3}$ ), $0.5 \mathrm{~g} \mathrm{P}$ (as $\mathrm{KH}_{2} \mathrm{PO}_{4}$ ), $1.2 \mathrm{~g} \mathrm{~K}$ (as $\mathrm{KH}_{2} \mathrm{PO}_{4}$ and $\mathrm{KCl}$ ), and $0.2 \mathrm{~g}$ $\mathrm{Mg}$ (as $\mathrm{MgSO}_{4} \cdot 7 \mathrm{H}_{2} \mathrm{O}$ ). Ammonium saltpeter was added during the growing season at $0.7 \mathrm{~g} \mathrm{~N}$ pot $^{-1}$. An additional $0.8 \mathrm{~g} \mathrm{~N}_{\text {pot }}^{-1}$ (as $\mathrm{NH}_{4} \mathrm{NO}_{3}$ ) and $1.2 \mathrm{~g} \mathrm{~K}_{\text {pot }}{ }^{-1}$ (as $\mathrm{KCl}$ ) were incorporated into the soil before sowing white mustard in the second year. During the growing season, $0.7 \mathrm{~g} \mathrm{~N}_{\text {pot }}{ }^{-1}$ (as $\mathrm{NH}_{4} \mathrm{NO}_{3}$ ) was added.

Dried and ground plant samples were mineralized (separately from each pot) in a mixture of concentrated $\mathrm{HNO}_{3}, \mathrm{HClO}_{4}$, and $\mathrm{H}_{2} \mathrm{SO}_{4}$ acids at a 40:10:1 ratio. Zinc content in mineralized samples was determined by atomic absorption spectrophotometry (AA-6800 Series Atomic Absorption Spectrophotometer, Shimadzu, Kyoto, Japan). Soil samples were air-dried and passed through a 2-mm sieve. Soil was analyzed before establishing the experimental treatments for available forms of $\mathrm{Zn}$ after extraction in $1 \mathrm{M} \mathrm{HCl}$ with a $1: 10$ soil solution ratio (Gembarzewski et al., 1987), $\mathrm{pH}$ in $1 \mathrm{M} \mathrm{KCl} \mathrm{(1:2.5}$ soil:solution ratio) by the potentiometric method, and organic $\mathrm{C}$ content by the method proposed by Kurimies (Walinga et al., 1992). Granulometric composition was determined by laser diffraction (Mastersizer 2000 particle size analyzer, Malvern Instruments Ltd., Malvern, UK) (Buurman et al., 1997). After the mustard harvest, soil samples were collected from each pot and $\mathrm{Zn}$ was determined by atomic absorption spectroscopy after extraction in $1 \mathrm{M} \mathrm{HCl}$ with a 1:10 soil:solution ratio.

Results were processed by ANOVA for a onefactorial pot experiment with a completely randomized orthogonal design. Differences among means (1\% level of significance) were tested by Tukey's HSD test with the PC STATISTICA program version 7.0 (StatSoft, Tulsa, Oklahoma, USA). The relationships between selected parameters were determined by correlation and regression analyses.

\section{RESULTS AND DISCUSSION}

Applying 25, 50, and $100 \mathrm{mg} \mathrm{Zn} \mathrm{kg}{ }^{-1}$ soil did not lead to significant differences in sunflower biomass compared with the control treatment with naturally occurring $\mathrm{Zn}$ levels (Table 1). Plant yield decreased significantly after applying $200 \mathrm{mg} \mathrm{Zn} \mathrm{kg}^{-1}$ soil. In this treatment, sunflower biomass yield was less than half of the amount reported

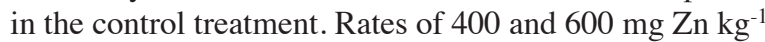
soil inhibited germination of sunflower seeds and led to complete plant death. In a previous experiment (Zalewska, 2012) investigating perennial ryegrass grown in soil with the granulometric composition of sand, applying 200 and $400 \mathrm{mg} \mathrm{Zn} \mathrm{kg}^{-1}$ soil also inhibited seed germination and plant growth and biomass yield of the first regrowth decreased by $31 \%$ and $52 \%$, respectively, but complete plant death was not reported. Baran (2013) revealed that maize is less sensitive to $\mathrm{Zn}$-polluted soil. In her research, applying 250 and $750 \mathrm{mg} \mathrm{Zn} \mathrm{kg}^{-1}$ soil reduced biomass of above-ground plant parts by $10 \%$ and $25 \%$, respectively (Baran, 2011).

White mustard was grown in the second year of the study. Similar to sunflower treatments, applying 25, 50 , and $100 \mathrm{mg} \mathrm{Zn} \mathrm{kg}^{-1}$ soil did not produce significant differences in the yield of mustard plants (Table 1). Unlike sunflower treatments, introducing $200 \mathrm{mg} \mathrm{Zn} \mathrm{kg}^{-1}$ soil did not inhibit mustard plant growth. The yield of mustard plants in this treatment was even significantly higher compared with other treatments and could be attributed

Table 1. Effect of $\mathrm{Zn}$-contaminated soil on green mass yield, $\mathrm{Zn}$ content in sunflower and white mustard, and $\mathrm{Zn}$ content in soil (extraction with $1 \mathrm{M} \mathrm{HCl}$ ) after harvesting plants.

\begin{tabular}{|c|c|c|c|c|c|}
\hline \multirow[b]{2}{*}{$\mathrm{Zn}$ rate } & \multicolumn{2}{|c|}{ Yield } & \multicolumn{2}{|c|}{ Zn content } & \multirow{2}{*}{$\begin{array}{l}\mathrm{Zn} \text { content } \\
\text { in soil } \\
\text { after } 2 \mathrm{yr}\end{array}$} \\
\hline & Sunflower & $\begin{array}{l}\text { White } \\
\text { mustard }\end{array}$ & Sunflower & $\begin{array}{l}\text { White } \\
\text { mustard }\end{array}$ & \\
\hline $\mathrm{mg} \mathrm{Zn} \mathrm{kg}{ }^{-1}$ soil & \multicolumn{2}{|c|}{ g DM pot ${ }^{-1}$} & \multicolumn{2}{|c|}{$\mathrm{mg} \mathrm{Zn} \mathrm{kg}{ }^{-1} \mathrm{DM}$} & $\mathrm{mg} \mathrm{Zn} \mathrm{kg}{ }^{-1}$ \\
\hline 0 & $79.4 \mathrm{a}$ & $56.7 \mathrm{a}$ & $57.26 \mathrm{e}$ & $29.64 \mathrm{e}$ & $11.21 \mathrm{f}$ \\
\hline 25 & $80.2 \mathrm{a}$ & $59.0 \mathrm{a}$ & $155.70 \mathrm{~d}$ & $64.80 \mathrm{~d}$ & $30.66 \mathrm{ef}$ \\
\hline 50 & $77.4 \mathrm{a}$ & $56.1 \mathrm{a}$ & $252.44 \mathrm{c}$ & $87.66 \mathrm{~d}$ & $50.34 \mathrm{e}$ \\
\hline 100 & $74.8 \mathrm{a}$ & $63.7 \mathrm{a}$ & $514.63 b$ & $148.48 \mathrm{c}$ & $93.90 \mathrm{~d}$ \\
\hline 200 & $30.5 b$ & $84.5 b$ & $898.40 \mathrm{a}$ & $422.20 b$ & $190.29 \mathrm{c}$ \\
\hline 400 & $-c$ & $26.1 \mathrm{c}$ & - & $1118.50 \mathrm{a}$ & $397.17 b$ \\
\hline 600 & $-c$ & $-d$ & - & - & $645.35 \mathrm{a}$ \\
\hline
\end{tabular}

Mean values in the same column followed by different letters indicate significant differences according to Tukey's test $(\mathrm{P} \leq 0.01)$. 
to higher nutrient concentrations $(\mathrm{N}, \mathrm{K}$, and $\mathrm{P})$ remaining in the soil after sunflower cultivation and the conversion of $\mathrm{Zn}$ into less soluble forms. In the first year of the study, applying $200 \mathrm{mg} \mathrm{Zn} \mathrm{kg}^{-1}$ soil led to a significant decrease in sunflower yield, and high quantities of unused $\mathrm{N}, \mathrm{K}$, and $\mathrm{P}$ could have remained in the soil. Zinc exerted a negative effect on mustard plants beginning at $400 \mathrm{mg} \mathrm{Zn}$ $\mathrm{kg}^{-1}$ soil, which reduced biomass yield by $50 \%$ compared with the control. Applying $600 \mathrm{mg} \mathrm{Zn} \mathrm{kg}^{-1}$ soil completely inhibited white mustard plant growth.

Applying increasing $\mathrm{Zn}$ rates significantly elevated its concentration in sunflower and mustard plants (Table 1). A strong positive correlation was observed between the level of $\mathrm{Zn}$-contaminated soil and $\mathrm{Zn}$ concentrations in plants; this was demonstrated by high determination coefficient values (Figures 1 and 2). A similar relationship has also been observed by Cardwell et al. (2002) and Deng et al. (2004) for $\mathrm{Zn}$ accumulation by some wetland plants. Zinc easily penetrates plant cells. Applying $200 \mathrm{mg} \mathrm{Zn} \mathrm{kg}^{-1}$ soil increased concentrations to $898 \mathrm{mg} \mathrm{Zn} \mathrm{kg}^{-1}$ sunflower DM (nearly 16-fold increase compared with control treatment) and $422 \mathrm{mg} \mathrm{Zn} \mathrm{kg}^{-1}$ mustard DM (nearly 14-fold increase compared with control treatment). A significant increase

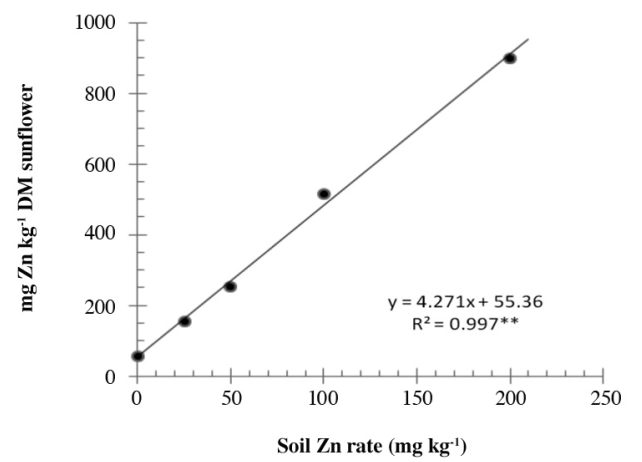

*** Correlation is significant at 0.01 level.

Figure 1. Relationship between the level of $\mathrm{Zn}$-contaminated soil and $\mathrm{Zn}$ concentration in sunflower.

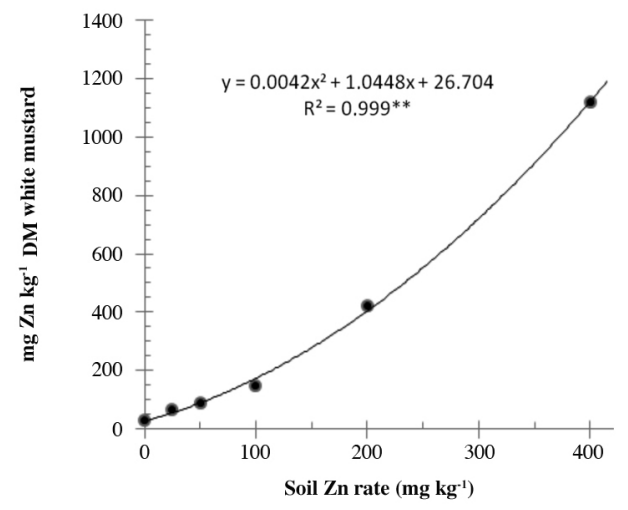

${ }^{* * *}$ Correlation is significant at 0.01 level.

Figure 2. Relationship between the level of $\mathrm{Zn}$-contaminated soil and $\mathrm{Zn}$ concentration in white mustard. in $\mathrm{Zn}$ concentrations was also noted in treatments with low levels of the analyzed metal (25 and $50 \mathrm{mg} \mathrm{Zn} \mathrm{kg} \mathrm{Zn}^{-1}$ soil), particularly in sunflower plants. The ease of $\mathrm{Zn}$ penetration into plant cells poses a significant threat to agriculture even in soils with low levels of the examined heavy metal.

Concentrations of 20 to $80 \mathrm{mg} \mathrm{Zn} \mathrm{kg}^{-1} \mathrm{DM}$ in plants are sufficient to meet crop plant requirements. A very high increase in $\mathrm{Zn}$ concentrations in sunflower and mustard plants, which was proportional to the soil contamination level, suggests that the analyzed metal easily penetrates the cell wall and plasma membranes of root cells. Zinc is easily absorbed by plants because it is one of the most mobile soil elements. According to Chaney (1993), toxic effects of $\mathrm{Zn}$ are most often manifested on leaves at concentrations higher than $300 \mathrm{mg} \mathrm{Zn} \mathrm{kg}^{-1} \mathrm{DM}$; in highly-sensitive plants, symptoms of toxicity can be observed at concentrations below $100 \mathrm{mg} \mathrm{Zn} \mathrm{kg}^{-1}$ leaf DM (Marschner 1995). In the current experiment, toxic effects of $\mathrm{Zn}$ were not observed even at concentrations of $515 \mathrm{mg}$ $\mathrm{Zn} \mathrm{kg}{ }^{-1}$ sunflower DM and $422 \mathrm{mg} \mathrm{Zn} \mathrm{kg}^{-1}$ mustard DM; this suggests that the analyzed plants are highly resistant to high tissue $\mathrm{Zn}$ levels. The growth and development of sunflower and white mustard plants were not inhibited when tissue $\mathrm{Zn}$ concentrations exceeded 5-fold optimal levels. Results of a previous study of perennial ryegrass validate the above observation (Zalewska, 2012). The cited study also demonstrated that toxic effects of $\mathrm{Zn}$ on plants are determined by soil cation exchange capacity. A higher soil mineral and organic colloid content has protective effects; it significantly reduces concentrations of active forms of $\mathrm{Zn}$ in soil, thus minimizing $\mathrm{Zn}$ toxicity.

In the present study, $\mathrm{Zn}$ concentrations were 2- to 3.5-fold higher in sunflower plants than in white mustard plants at corresponding levels of $\mathrm{Zn}$ pollution. This difference could be attributed to a drop in the concentrations of readily soluble forms of $\mathrm{Zn}$ in the soil during the experiment that limited the transfer of $\mathrm{Zn}$ to mustard plants.

Zinc uptake by sunflower plants increased proportionally with a rise in soil contamination levels from 25 to $100 \mathrm{mg} \mathrm{Zn} \mathrm{kg}^{-1}$ soil (Table 2). A reduction in biomass yield after applying $200 \mathrm{mg} \mathrm{Zn} \mathrm{kg}^{-1}$ soil led to a decrease in Zn uptake by sunflower plants. A similar dependency was observed in mustard plants, but $\mathrm{Zn}$ uptake was considerably reduced only in treatments containing $400 \mathrm{mg} \mathrm{Zn} \mathrm{kg} \mathrm{Zn}^{-1}$ soil due to a significant decrease in mustard biomass (Table 2). The coefficient of determination illustrating the correlation between total $\mathrm{Zn}$ uptake by sunflower and white mustard plants and the level of $\mathrm{Zn}$-contaminated soil reached a very high value of $\mathrm{R}^{2}=0.99$ (Figure 3 ). Total $\mathrm{Zn}$ uptake by sunflower and mustard plants accounted for only $1 \%$ to $8 \%$ of the $\mathrm{Zn}$ rate incorporated into the soil. Despite high concentrations of $\mathrm{Zn}$ in plant tissues, soil postharvest content did not decrease significantly at the end 
Table 2. Effect of Zn-contaminated soil on $\mathrm{Zn}$ uptake by sunflower and white mustard.

\begin{tabular}{|c|c|c|c|c|c|c|c|}
\hline \multicolumn{2}{|c|}{$\mathrm{Zn}$ rate } & \multicolumn{4}{|c|}{ Zn uptake } & \multicolumn{2}{|c|}{ Total Zn uptake } \\
\hline \multirow[b]{2}{*}{$\mathrm{mg} \mathrm{Zn} \mathrm{kg}{ }^{-1}$ soil } & \multirow[b]{2}{*}{$\mathrm{mg} \mathrm{Zn} \operatorname{pot}^{-1}$} & \multicolumn{2}{|c|}{ Sunflower } & \multicolumn{2}{|c|}{ White mustard } & \multirow[b]{2}{*}{$\mathrm{mg} \mathrm{Zn} \operatorname{pot}^{-1}$} & \multirow[b]{2}{*}{$\% \mathrm{Zn}$ rate } \\
\hline & & $\mathrm{mg} \mathrm{Zn}$ pot $^{-1}$ & $\% \mathrm{Zn}$ rate & $\mathrm{mg} \mathrm{Zn}$ pot $^{-1}$ & $\% \mathrm{Zn}$ rate & & \\
\hline 0 & 0 & 4.55 & - & 1.68 & - & 6.23 & - \\
\hline 25 & 200 & 12.49 & 6.24 & 3.82 & 1.91 & 16.31 & 8.15 \\
\hline 50 & 400 & 19.54 & 4.89 & 4.92 & 1.23 & 24.46 & 6.12 \\
\hline 100 & 800 & 38.49 & 4.81 & 9.46 & 1.18 & 47.95 & 5.99 \\
\hline 200 & 1600 & 27.40 & 1.71 & 35.68 & 2.23 & 63.08 & 3.94 \\
\hline 400 & 3200 & - & - & 29.19 & 0.91 & 29.19 & 0.91 \\
\hline 600 & 4800 & - & - & - & - & - & - \\
\hline
\end{tabular}

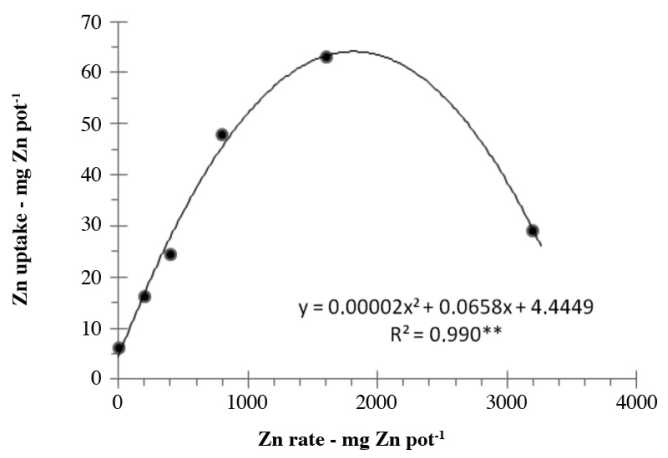

${ }^{* * *}$ Correlation is significant at 0.01 level.

Figure 3. Relationship between the level of $\mathrm{Zn}$-contaminated soil and total $\mathrm{Zn}$ uptake by sunflower and white mustard.

of the 2-yr experiment (Table 1). In a study by Gworek et al. (2003), who analyzed phytoremediation efficiency in soils contaminated with heavy metals, $\mathrm{Zn}$ uptake by harvested plants did not exceed $2.5 \%$ of the mobile $\mathrm{Zn}$ fraction. Similar Zn uptake levels were reported by Antonkiewicz and Jasiewicz (2003) in a study of maize. The low efficiency of phytoremediation techniques could also be attributed to the fact that analyzed samples of post-harvest soil contained small root fragments that are characterized by substantially higher concentrations of heavy metals than above-ground plant parts (Deng et al., 2004; Zalewska, 2010). This undoubtedly influences $\mathrm{Zn}$ soil concentrations after harvest.

\section{CONCLUSIONS}

Sunflower and white mustard can accumulate large amounts of $\mathrm{Zn}$ and are relatively resistant to high $\mathrm{Zn}$ soil concentrations; therefore, they can be used for $\mathrm{Zn}$ phytoextraction of moderately contaminated soil (approximately $200 \mathrm{mg} \mathrm{Zn} \mathrm{kg}^{-1}$ soil). Cultivation of the test plants allowed removal of approximately $20 \mathrm{~kg} \mathrm{Zn} \mathrm{ha-1}$ contaminated soil. In the short term, tested crops would not effectively remove $\mathrm{Zn}$ from the soil. However, in the long run, the growing of crops could reduce $\mathrm{Zn}$ contamination levels in the soil. Moreover, relatively high tolerance of sunflower and white mustard to $\mathrm{Zn}$ contamination and the rapid growth of these species are possible alternatives for phytostabilization of $\mathrm{Zn}$-contaminated soil.

\section{LITERATURE CITED}

Antonkiewicz, J., and C. Jasiewicz. 2003. Assessment of usability of maize (Zea mays L.) in phytoextraction of cadmium, lead, nickel, copper and zinc from soil contaminated with these metals. Acta Scientiarum Polonorum Formatio Circumiectus 2(1):61-69.

Baran, A. 2011. Maize response to toxic zinc content in soil. Proceedings of ECOpole 5:155-160.

Baran, A. 2013. Assessment of Zea mays sensitivity to toxic content of zinc in soil. Polish Journal of Environmental Studies 22:77-83.

Blaylock, M.J., D.E. Salt, S. Dushenkov, O. Zakhrova, C. Gussman, Y. Kapulnik, et al. 1997. Enhanced accumulation of $\mathrm{Pb}$ in Indian mustard by soil-applied chelating agents. Environmental Science and Technology 13:860-865.

Buurman, P., T. Pape, and C.C. Muggler. 1997. Laser grain-size determination on soil genetic studies. 1. Practical problems. Soil Science 162(3):211-218.

Cardwell, A.J., D.W. Hawker, and M. Greenway. 2002. Metal accumulation in aquatic macrophytes from southeast Queensland. Chemosphere 48:653-663.

Chaney, R.L. 1983. Plant uptake of inorganic waste constituents. p. 50-76. In Parr, J.E., P.B. Marsh, and J.M. Kla (eds.) Land treatment of hazardous wastes. Noyes Data Corporation, Park Ridge, New Jersey, USA.

Chaney, R.L. 1993. Zinc phytotoxicity. p. 135-150. In Robson, A.D. (ed.) Zinc in soil and plants. Kluwer Academic Publishers, Dordrecht, The Netherlands.

Clemens, S., M.G. Palmgren, and U. Krämer. 2002. A long way ahead: Understanding and engineering plant metal accumulation. Trends in Plant Science 7:309-315.

Deng, H., Z.H. Yea, and M.H. Wonga. 2004. Accumulation of lead, zinc, copper and cadmium by 12 wetland plant species thriving in metal-contaminated sites in China. Environmental Pollution 132:29-40.

Ernst, W.H.O. 2000. Evolution of metal hyperaccumulation and phytoremediation hype. New Phytologist 146:357-358.

Gembarzewski, H., W. Kamińska, and J. Korzeniowska. 1987. Application of $1 \mathrm{~mol} \mathrm{dm}^{-3}$ solution of $\mathrm{HCl}$ as a common extractor for the estimation of the content of available forms of microelements in soils. p. 1-9. Prace Komitetu Naukowego PTG, Warszawa, Polska.

Gworek, B., K. Jeske, and J. Kwapisz. 2003. The phytoremediation of soils contaminated with heavy metals using sequential extraction method. Archives of Environmental Protection 29(4):71-79.

Huang, J.W., J. Chen, W.R. Berti, and S.D. Cunningham. 1997. Phytoremediation of lead contaminated soils: Role of synthetic chelates in lead phytoextraction. Environmental Science and Technology 31:800-805.

Kärenlampi, S., H. Schat, J. Vangronsveld, J.A.C. Verkleij, D. van der Lelie, M. Mergeay, et al. 2000. Genetic engineering in the improvement of plants for phytoremediation of metal polluted soil. Environmental Pollution 107:225-231.

Krämer, U. 2005. Phytoremediation: Novel approaches to cleaning up polluted soils. Current Opinion in Biotechnology 16:133-141. 
Krämer, U., J.D. Cotter-Howells, J.M. Charnock, A.J.M. Baker, and J.A.C. Smith. 1996. Free histidine as a metal chelator in plants that accumulate nickel. Nature 379:635-638.

Lasat, M.M., S.D. Ebbs, and L.V. Kochian. 1998. Phytoremediation of a radiocesium-contaminated soil: Evaluation of cesium-137 bioaccumulation in the shoots of three plant species. Journal of Environmental Quality 27:165-169.

Marschner, H. 1995. Mineral nutrition of higher plants. 889 p. $2^{\text {nd }} e d$. Academic Press, London, UK.

Pavlíková, D., T. Macek, M. Macková, M. Surá, J. Száková, and P. Tlustoš. 2004. The evaluation of cadmium, zinc and nickel accumulation ability of transgenic tobacco bearing different transgenes. Plant, Soil and Environment 50:513-517.

Salt, D.E., R.C. Prince, A.J.M. Baker, I. Raskin, and I.J. Pickering. 1999. Zinc ligands in the metal hyperaccumulator Thlaspi caerulescens as determined using X-ray absorption spectroscopy. Environmental Science and Technology 3:713-717.

Sas-Nowosielska, A., R. Kucharski, E. Małkowski, M. Pogrzeba, J.M. Kuperberg, and K. Kryński. 2004. Phytoextraction crop disposal - an unsolved problem. Environmental Pollution 128:373-379.
Terelak, H., C. Pietruch, and A. Tujaka. 2002. Zinc in the surface layers of farm-land soils in Poland. Polish Journal of Soil Science 35(2):45-51.

Terelak, H., T. Stuczyński, and M. Piotrowska. 1997. Heavy metals in agricultural soils in Poland. Polish Journal of Soil Science 30(2):35-42.

Vaněk, A., L. Borůvka, O. Drábek, M. Mihaljevič, and M. Komárek. 2005. Mobility of lead, zinc and cadmium in alluvial soils heavily polluted by smelting industry. Plant, Soil and Environment 51:316-321.

Walinga, I., M. Kithome, N. Novozamsky, V.J.G. Houba, and J.J. Vander Lee. 1992. Spectrophotometric determination of organic carbon in soil. Communications in Soil Science and Plant Analysis 23:1935-1944

Zalewska, M. 2010. Effect of soil contamination by $\mathrm{Pb}, \mathrm{Ni}$ and $\mathrm{Cd}$ and VA mycorrhizal fungi on yield and heavy metal concentration in roots and aboveground biomass of oat. Ecological Chemistry and Engineering A 17(4-5):541-548.

Zalewska, M. 2012. Response of perennial ryegrass (Lolium perenne L.) to soil contamination with zinc. Journal of Elementology 17:329-343. 